\title{
SULINDAC SULFIDE INDUCES APOPTOSIS OF BREAST CANCER CELLS ACTIVATED BY CO-CULTURE MODEL: A MECHANISM MEDIATED BY RAS SIGNALING PATHWAY. \\ BY
}

\author{
Nadia A. Thabet ${ }^{\mathrm{a}}$, El-Guendy N ${ }^{\mathrm{a}}$, Mona Mostafa Mohamed ${ }^{\mathrm{b}}$ and Samia A. Shouman \\ FROM \\ ${ }^{a}$ Department of Cancer biology, National Cancer Institute, Cairo University, Giza \\ 12613, Egypt. \\ ${ }^{\mathrm{b}}$ Department of Zoology, Faculty of Sceince, Cairo University, Giza 12613, Egypt.
}

\begin{abstract}
Macrophage-epithelial interactions play a crucial role in breast cancer progression and metastasis. Tumor associated macrophages (TAMs) provide the tumor microenvironment with multiple inflammatory mediators that stimulate several signaling pathways which participate in survival and growth of cancer cells, thus they have become an attractive target for chemotherapeutic agents. Sulindac Sulfide is one of NSAIDs and its anticancer activity in prevention of tumor incidence and progression has been documented in several types of cancer. The aim of this study was to test the effects of media conditioned by U937 human monocytes (U937-CM) as well as the effect of Sulindac Sulfide on the survival oncogenic expression and apoptosis of MCF-7 cells. The results showed that U937-CM enhanced MCF-7 survival and proliferation through significant increase in Ras expression which resulted in upregulation of antiapoptotic protein Bcl-2 and down regulation of tumor suppressor Par-4. Sulindac Sulfide treatment inhibited the growth of induced cells by inhibition of Ras expression and its downstream signaling. Suppression of Ras is accompanied by activation of apoptotic machinery through down regulation of Bcl-2 and upregulation of Par-4 that resulted in significant activation of caspase-3. The current data demonstrate that Sulindac Sulfide succeeded in suppressing the paracrine effect of TAMs on breast cancer cells suggesting the promising role in breast cancer treatment.
\end{abstract}

Key words: Par-4, Ras, Sulindac Sulfide and TAMs.

\section{Introduction}

Breast cancer $(\mathrm{BC})$ is the most frequently diagnosed cancer globally and it represents the first cause of death overall in women between 40 and 59 years of age (Siegel et al., 2015). BC does not only depend on growth and progression of breast tumor cells and their malignant potential, but also on the multidirectional interactions between tumor cells and stromal cells and their secretions in the tumor microenvironment (TME) (Hanchen et al., 2007; Joyce and Pollard 2009). So, TME plays a crucial role in tumor progression and therapeutic response (Faurobert et al., 2015; Klemm and Joyce 2015).

Among major cells that constitute about $40 \%$ of tumor breast microenvironment are macrophages (Bingle et al., 2002). Once macrophages are recruited to the primary tumor, they respond to many stimuli and differentiat into tumor associated macrophages (TAMs) (Qian and Pollard, 2010). The resulting TAMs are able to secrete multiple inflammatory cytokines in TME which induce several intracellular signaling pathways 
that stimulate cancer progression and invasion (Dhillon et al. 2007; Roberts and Der 2007). Therefore, inflammation emerged as the seventh hallmark of cancer which represents a target for innovative therapeutic strategies and prevention (Colotta et al., 2009).

Epidemiological studies indicate have showed that continuous intake of NSAIDs is associated with a significant decrease in cancer incidence and delayed progression in patients with colorectal, breast, lung and other cancers(Cha and DuBois, 2007; Zhao et al.,2009; Ruder e t al., 2011). Inhibition of cyclooxygenase (Cox) activity and prostaglandin synthesis is the primary mechanism responsible for antineoplatic activities of NSAIDs but it is not the only mechanism (Piazza et al., 2009). Sulindac sulfide is non-selective NSAIDs that exert their anti-neoplastic activities though their multiple effects on cancer cells and their microenvironment (Gurpinar et al., 2014).

In this study we investigated the effect of conditioned media (U937-CM) on MCF-7 cells and Sulindac Sulfide on the activated MCF-7 on cellular proliferation and apoptosis through Ras and Par-4 expression.

\section{Materials and Methods}

\section{Drug and Chemicals}

Sulindac Sulfide, RPMI-1640 Medium, fetal bovine serum (FBS), dimethylsulfoxide (DMSO), $\beta$-mercaptoethanol, phorbol myristate acetate (PMA), sodium dodecyl sulfate (SDS), sodium bicarbonate and trichloroacetic acid (TCA) were all purchased from Sigma Aldrich Chemical Co. (St. Louis, MO, USA). Triton X-100 was procured from MP Biochemical (Santa Ana, California, USA). All other chemicals and reagents were from standard analytical grade.

\section{Cell lines:}

Breast carcinoma cell line (MCF7) and Human monocytic cell line (U937) were maintained in RPMI-1640 media supplemented with 10\% FBS, $1 \%$ L-glutamine, $1 \%$ penicillin/streptomycin in humid atmosphere of $5 \% \mathrm{CO}_{2}$ at $37^{\circ} \mathrm{C}$. U937 cells were grown in suspension and were split for passaging while MCF7 cells were passaged by trypsinization .

\section{Preparation of human monocytes U937 condition media (U937-CM)}

U937 cells were seeded at density of $2.5 \times 10^{5}$ cells $/ \mathrm{ml}$ in RPMI complete medium into T-75 tissue culture flask and grown to approximately $80 \%$ confluence. Cells were collected washed twice with PBS. Cells were treated with 100 nM PMA for $48 \mathrm{hr}$ to differentiate them into macrophages then activated by overnight treating with lipopolysaccharide $(1 \mu \mathrm{g} / \mathrm{ml})$ for $24 \mathrm{hr}$. cells washed twice with PBS and incubated overnight in serum free medium. Overnight condition media (CM) were collected and centrifuged at $2000 \mathrm{~g}$ at $4^{0} \mathrm{C}$ for $10 \mathrm{~min}$ to remove cell debris. 


\section{Proliferation assay and Cytotoxicity assay:}

Breast cancer cell lines were seeded at density $3 \times 103$ cells/well in 96-well plate in RPMI containing 5\% FBS. $24 \mathrm{~h}$ after seeding, media was replaced with either RPMI containing 5\% FBS, U937-CM containing 5\% FBS, or U937-CM containing 5\% FBS and different concentrations of Sulindac Sulfide $(0,12.5,25,50,100 \mu \mathrm{M})$ and incubated for $48 \mathrm{~h}$. The cell growth and potential cytotoxicity of sulindac sufide were determined by the sulforhodamine B (SRB) assay as described by Skehan et al. 1990.

\section{Real time polymerase chain reaction}

Total cellular RNA was extracted following the protocol of the RNeasy Mini Kit (Qiagen, Valencia, CA). Reverse transcription was completed using High capacity cDNA archive kit (Applied Biosystem, California, USA). Real time PCR of Gapdh, Il$1 \beta$, Il-6, Ras and Par-4were performed in triplicate on an ABI 7500 Fast Real-Time PCR System using the GoTaq PCR master mix (Promega, Madison, U.S.A). Fast amplification parameters as follows: one cycle at $95{ }^{\circ} \mathrm{C}$ for $10 \mathrm{~min}$, followed by 40 cycles at $95{ }^{\circ} \mathrm{C}$ for $15 \mathrm{~s}$, and $60{ }^{\circ} \mathrm{C}$ for $1 \mathrm{~min}$. All primers used in this study were purchased from Invitrogen (California, USA) (Table 1). Quantitative analysis of data was performed by using the $\Delta \Delta \mathrm{Ct}$ method (Livak and Schmittgen, 2001). Values were normalized to GAPDH and were expressed as relative expression levels.

Table(1): The primer sequences of GAPDH, Ras and Par-4 genes:

\begin{tabular}{|c|c|c|}
\hline Gene & Forward & Reverse \\
\hline GAPDH & $\begin{array}{c}5- \\
\text { TGAAGGTCGGAGTCAACGGATTT- } \\
3\end{array}$ & $\begin{array}{c}5- \\
\text { GCCATGGAATTTGCCATGGGTGG- } \\
3\end{array}$ \\
\hline Ras & 5-GGGGAGGGCTTTCTTTGTGTA-3 & 5-GTCCTGAGCCTGTTTTGTGTC -3 \\
\hline Par-4 & $\begin{array}{c}\text { 5-GCCGCAGAGTGCTTAGATGAG- } \\
3\end{array}$ & $\begin{array}{c}5- \\
\text { GCAGATAGGAACTGCCTGGATC - } \\
3\end{array}$ \\
\hline
\end{tabular}

\section{Preparation of cell lysate}

MCF-7 cells were grown at a density of 250,000 cell $/ \mathrm{ml}$ in $75 \mathrm{~T}$-flasks containing RPMI-1640 supplemented with5\% FBS for $24 \mathrm{~h}$ at $37 \mathrm{C}$ in a humidified $\mathrm{CO} 2$ incubator. After 24h, media was replaced with either RPMI containing 5\% FBS, U937-CM containing 5\% FBS, or U937-CM containing 5\% FBS and $25 \mu \mathrm{M}$ Sulindac Sulfide and incubated for $48 \mathrm{~h}$. Experiments were run in triplicate. After $48 \mathrm{~h}$, media were collected and stored at $-80 \mathrm{C}$ for future experiments and Cells were collected by trypsinization then lysed with RIPA lysis buffer (25 mM Tris HCL pH 7.6, $150 \mathrm{mM}$ $\mathrm{NaCl}, 1 \%$ Triton $\mathrm{X}-100,1 \%$ Sodium deoxycholate and $0.1 \%$ SDS) containing protease inhibitors. Cell lysates were sonicated on ice in a $50 \mathrm{~W}$ Ultrasonicator five times for five seconds. Protein concentrations in the media and cell lysates were determined by Bradford (Bardford 1976) using kit (Pierce, Rockford, IL, USA). 


\section{Western blot}

Protein concentrations of MCF-7 cells were measured as previously mentioned. The lysates were separated by SDS-PAGE (12\% acrylamide) at protein concentration of $20 \mathrm{lg} /$ well. Gels were electrotransferred onto to polyvinyldiene difluoride membranes. The membranes were blocked with $5 \%$ non-fat dry milk and probed with specific primary antibodies of monoclonal anti-Bax, $\mathrm{Bcl} 2$ and $\beta$-actin antibodies followed by incubation with peroxidase-conjugated secondary antibodies. The blots were developed with Amersham ECL western blotting kit (GE Healthcare, Amersham Place, Little Chalfont, U.K) according to the manufacturer's instructions. Bands intensity was quantified with ImageJ software (National Institutes of Health, Bethesda, MA, USA) using $\beta$-actin as loading control.

\section{Assay of caspase-3 activity}

Caspase 3 activity was assessed spectrophotometrically at $450 \mathrm{~nm}$ in cell lysates using ELISA kit (Invitrogen, Carlsbad, CA, USA) following the manufacturer's instructions (Casciola-Rosen et al.,1996). Each concentration repeated two times and the experiment was carried out three independent times. The activity was calculated relative to the corresponding protein content.

\section{Statistical analysis:}

Data are represented as mean \pm standard deviation (SD). The data were analyzed by using one-way analysis of variance (ANOVA) test. To assess the significance of differences the Tukey post-hoc test was used and $p$ values less than 0.05 were considered to be statically significant. Graphs were performed using Prism software program (graph pad prism software, version 5, CA, USA) and analysis of data was performed using GraphPad InStat, version 5.

\section{Results}

\section{U937-CM enhances survival of MCF-7 cells while Sulindac Sulfide inhibits it:}

Figure 1 showed the effect of soluble factors secreted by U937 cells on the survival of MCF-7 cells then the treatment of these stimulated cells with various concentrations $(12.5-100 \mu \mathrm{M})$ of Sulindac Sulfide for $48 \mathrm{~h}$. U937-CM significantly $(\mathrm{p} \leq$ 0.05 ) increased MCF-7 cells survival by 1.6 fold after $48 \mathrm{~h}$ compared to control. On the other hand, the treatment with Sulindac Sulfide for $48 \mathrm{~h}$ caused a concentration dependent decrease in the survival of stimulated MCF-7 cells. The $\mathrm{IC}_{50}(50 \%$ inhibitory concentration) of Sulidac Sulfide was $50 \mu \mathrm{M}$. 


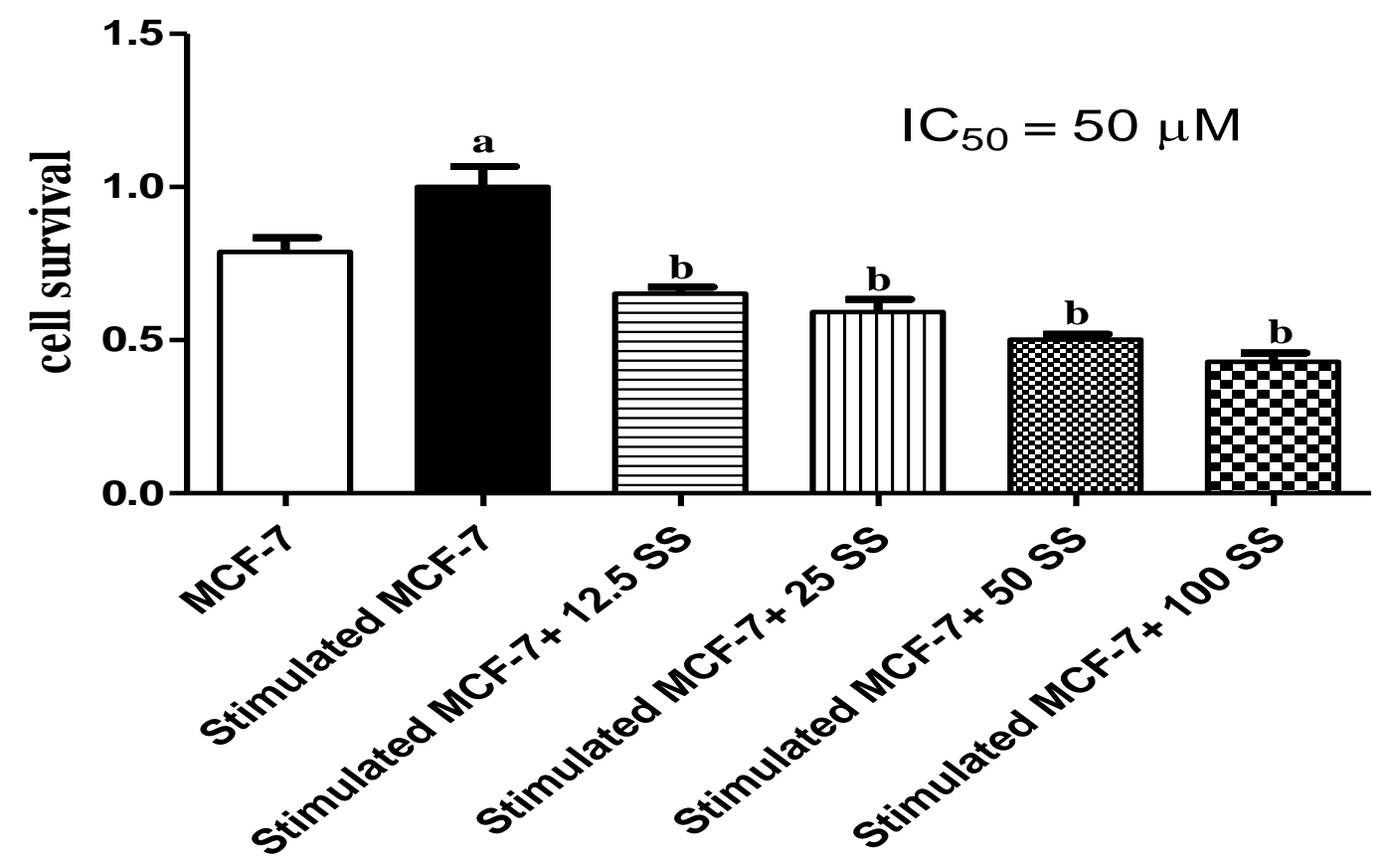

Figure.1. Histogram represents the effect of U937-CM and Sulindac Sulfide on survival of MCF-7 breast cancer cell using SRB assay. MCF-7 cells were seeded in the absence (control) or presence of U937-CM (stimulated MCF-7) or stimulated MCF -7 cells treated with different concentrations of Sulindac Sulfide $(0-100 \mu \mathrm{M})$ for $48 \mathrm{~h}$. Results are expressed as the mean $\pm \mathrm{SD}$ of 5 independent experiments performed in triplicate. Bars represent absorbance $(\mathrm{O} . \mathrm{D}=570 \mathrm{~nm})$, which is proportional to cell viability; "aa", Significantly different from control, “b” from stimulated MCF-7 at $P \leq 0.05$.

\section{Sulindac Sulfide inhibits Ras expression induced by U937-Cm in MCf-7 cells:}

Treatment of MCF-7 cells with U937-CM induced the expression of Ras mRNA in MCF-7 as detected by RT-PCR analysis. Our results showed that U937-CM increased Ras mRNA in MCF-7 by 2 folds after $48 \mathrm{~h}$. while, treatment of stimulated MCF-7 cells with $25 \mu \mathrm{M}$ Sulindac Sulfide for $48 \mathrm{~h}$ significantly reduced Ras expression to the half( Figure 2). 


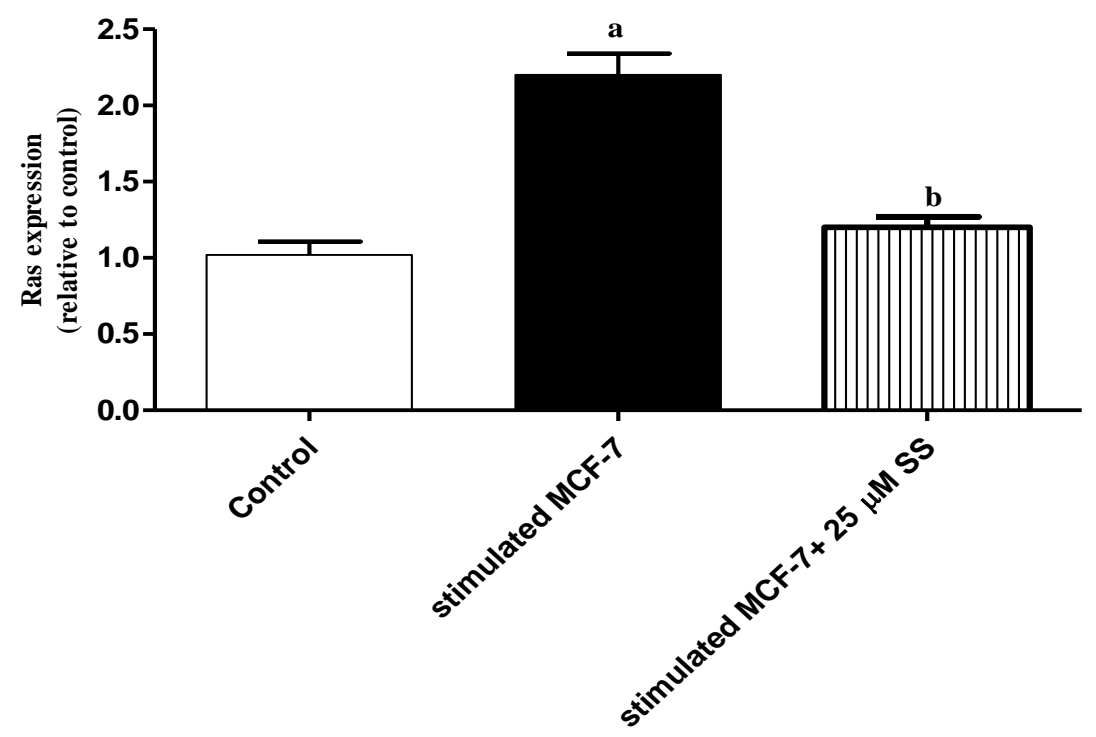

Figure.2. Histogram represents the effect of U937-CM and Sulindac Sulfide on the Ras gene expression. Results are expressed as means \pm SD of 2 independent experiments performed in duplicates for qPCR experiment. Significance was done by one way ANOVA using Tukey's multiple comparison test. "a"” Significantly different from control, “b” from stimulated MCF-7 at $P \leq 0.05$.

\section{Sulindac Sulfide induces apoptosis in MCF-7 cells stimulated with U937-CM:}

Our results revealed that after $48 \mathrm{~h}$ U937-CM increased anti-apoptotic Bcl-2 protein and decreased $(\mathrm{p} \leq 0.05)$ the Par-4 expression in MCF-7 cells to half compared to unstimulated cells. However, Sulindac Sulfide succeeded in increasing pro-apoptotic Par-4 expression and decreasing of the anti-apoptotic Bcl-2 protein. $25 \mu \mathrm{M}$ Sulindac Sulfide significantly elevated Par-4 expression level by 3.7 fold (Figure 3) and declined the expression of Bcl-2 protein by 0.18 fold (Figure 4) after $48 \mathrm{~h}$ of treatment compared to stimulated untreated cells. Furthermore, the increase in Par-4 expression and decrease in Bcl-2 level was accompanied by increase in caspase-3 activity. Where, treatment with $25 \mu \mathrm{M}$ Sulindac Sulfide for $48 \mathrm{~h}$ significantly increased caspase-3 activity 2.26 fold compared to the untreated stimulated cells (Figure 5). 


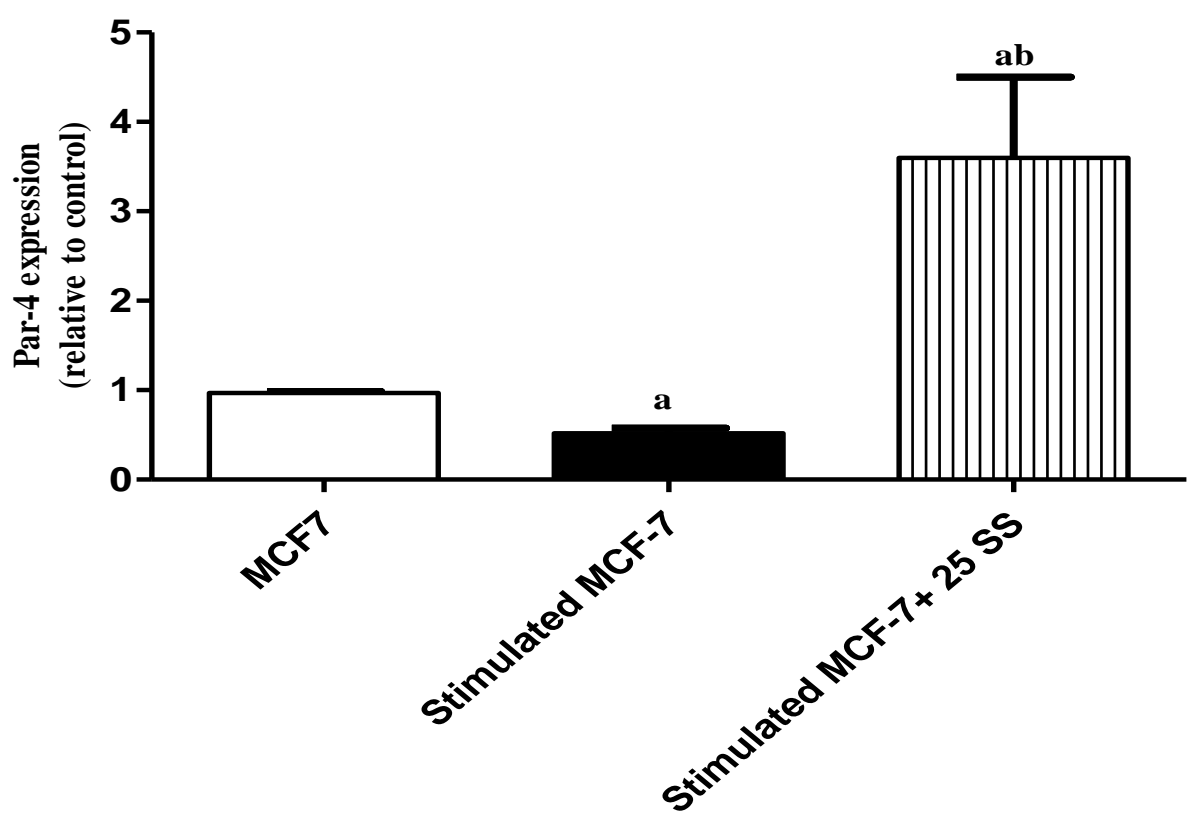

Figure.3. Histogram represents the effect of U937-CM and Sulindac Sulfide on the Par4 gene expression. Results are expressed as means \pm SD of 2 independent experiments performed in duplicates for qPCR experiment. Significance was done by one way ANOVA using Tukey's multiple comparison test. “a", Significantly different from control and “b”" from stimulated MCF-7.

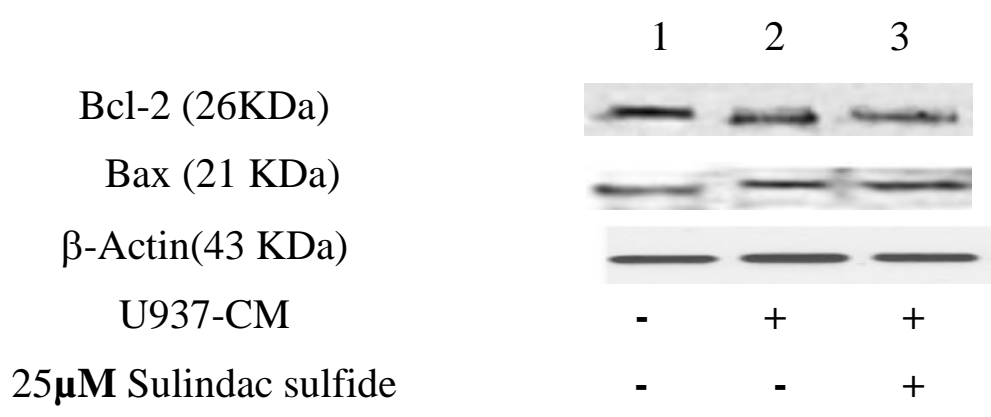

Figure.4. Immunoblot analysis show the effect of U937-CM and sulindac sulfide on Bcl-2 and Bax expression: Lane 1 shows Bcl-2 and BAX expression was by control MCF-7 cells. Lane 2 shows that U937-CM didn't alert the expression of Bax by MCF-7 cells while the expression Bcl-2 was increased after $48 \mathrm{~h}$. On the other hand, the treatment of stimulated MCF-7 cells with $25 \mu \mathrm{M}$ sulindac sulfide for $48 \mathrm{~h}$ decreased the Bcl-2 expression while Bax expression did not change as shown in lanes 3. 


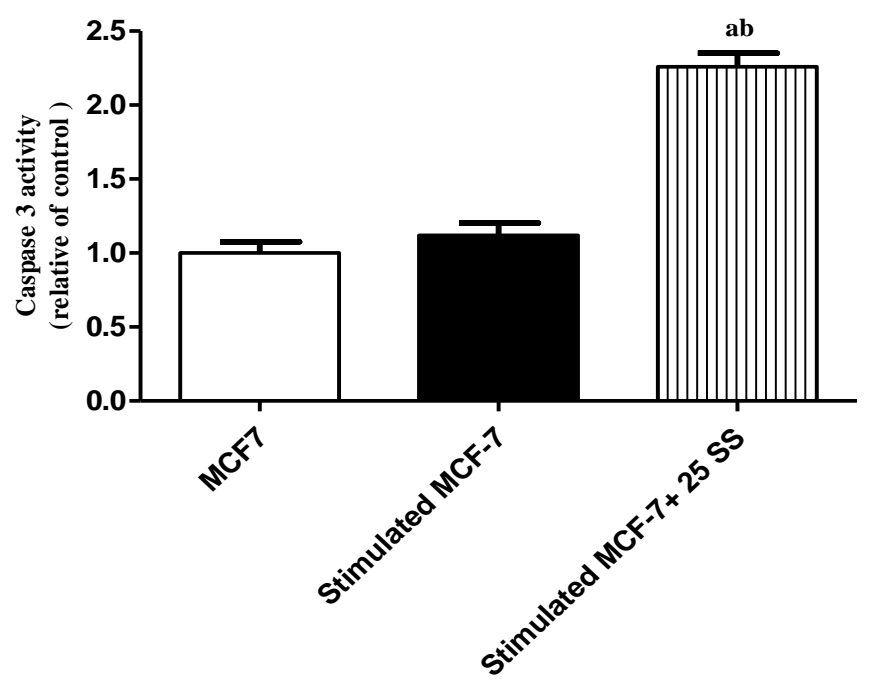

Figure.5. Effect of U937-CMand Sulindac Sulfide on Caspase-3 activity in MCF-7 cells. Results are expressed as means \pm SD of 2 independent experiments performed in duplicates. Significance was determined with one way ANOVA using Tukey's multiple comparison test. "aa" Significantly different from control and "bb" from stimulated MCF7.

\section{Discussion}

Macrophage-epithelial interactions play a crucial role in breast cancer progression and metastasis (Bingle et al., 2002; Qian and pollard 2010). TAMs provide the tumor microenvironment with multiple cytokines, chemokines, growth factors and proteases that stimulate signaling pathways associated with tumor growth, invasion, metastasis and therapeutic resistance (Condeelis and Pollard 2006).

Our data showed that treatment of MCF-7 cells with U937-CM significantly increased the proliferation and induced the expression of Ras mRNA in breast cancer cells. Similar increase in survival was found by Craig et al. (2008) who reported a significant increase in growth after Co-inoculation of PC-3 and PBMCs or U937-CM in vivo. The increased growth of MCF-7 by activated macrophages may be due to secreted mediators and cytokines which generate inflammatory tumor microenvironment. Inflammatory tumor microenvironment has many tumor-promoting effects. It aids in the proliferation and survival of malignant cells and promotes angiogenesis and metastasis. Additionally, inflammation can magnify oncogenic Ras activation to activate many downstream signaling cascades (Dibra et al., 2014 and Leibovich-rivkin 2014).

Accordingly, the increase in survival of these cells may be due to upregulation of Ras oncogene. Although, Ras mutations are rarely seen in breast cancer, Ras was found to be activated in $50 \%$ of breast tumors. A consequence of constitutive Ras activation is downstream changes in gene expression, which in turn act to modulate a variety of cellular processes. Activated Ras protects cells from apoptosis by modulation of a variety of pro-apoptotic and anti-apoptotic proteins, including down-regulation of Par-4 expression (Ahmed et al., 2008).

Par-4 is a pro-apoptotic tumor suppressor protein and has been proposed as an important target of therapeutic intervention since it does not cause apoptosis of normal 
or nontransformed cells (Ranganathan and Rangnekar 2005). It is found to be downregulated in various types of cancer such as neuroblastoma, endometrial cancer and renal carcinoma (Cook et al., 1999; Kogel et al., 2001; Moreno-Bueno et al., 2007). Although, Par-4 plays a crucial role in the activation of apoptosis and inhibition of cell survival, there are few studies investigates its role in modulating breast cancer proliferation and apoptosis. The apoptotic effect of Par-4 involves either activation of extracellular apoptotic machinery by formation of death-inducing signaling complex (DISC) which subsequently activate caspase 8 and downstream caspases or inhibition of pro-survival mechanisms (Chemaa et al., 2003 and Burikhanov et al., 2009). The present study showed that U937-CM promotes the survival and proliferation and suppresses apoptosis of non-invasive breast cancer MCF-7 cells though increasing the expression of Ras which in turn decreasing Par-4 and increasing Bcl-2 levels.

Because of the role of inflammatory microenvironment on tumor progression, researchers have been investigating the effect of NSAIDs in many types of cancer (Kwan et al., 2007). In the current study Sulindac Sulfide inhibited the survival of stimulated MCF-7 cells in a dose dependent manner. Several in vitro studies have also documented the anti-tumor of Sulindac Sulfide against many types of cancer cell lines. Tinsley et al., 2009 reported that Sulindac Sulfide inhibited the growth of the human SK-BR-3, ZR75-1, and MDA-MB-231 breast tumor cell lines with IC50 values of 59, 76 , and $84 \mu \mathrm{M}$, respectively. The ability of Sulindac Sulfide to suppress the growth and proliferation of cancer cells may be due to the direct inhibition of Cox-2 activity or suppression of other signaling pathways.

One of the pathways which suppressed by exposure to these drugs is RASMAPK pathway. Sulindac Sulfide was found to bind with Ras at Raf binding site inhibiting the activation of this downstream cascade (Gala et al., 2002). The present study revealed that Sulindac Sulfide decreased the expression of Ras in the stimulated MCF-7cells. Down regulation of Ras expression was accompanied by increasing the apoptosis markers. First, we found that the Par-4 expression was significantly upregulated in response to the exposure to Sulindac Sulfide. Upregulation of Par-4 was associated by a significant downregulation of Bcl-2 and a significant increase in caspase-3 activity while Bax was not changed. Previous study found that Sulindac stimulated the Par-4 expression in HCA-7carcinoma cells (Zhang and Dubois 2000). It was postulated that the increased expression of Par-4 decreased the antiapoptotic protein Bcl-2 expression in NIH3T3 fibroblasts, PC-3 prostate cancer cells (Nalca et al 1999), pancreatic cancer (Azmi et al., 2008) and neoplastic lymphocytes while Bax levels are not modified even with the addition of chemotherapeutic agents (Boehrer et al., 2002). Moreover, Flis et al. 2006 reported that Sulindac Sulfide induced apoptosis in endothelial cells via activation of caspase-3.

In conclusion, our data support a promising role of Sulindac Sulfide in suppressing breast cancer progression via decreasing survival pathway and activating apoptosis machinery. 


\section{REFERENCES}

Ahmed MM, Sheldon D, Fruitwala MA, Venkatasubbarao K, Lee EY, Gupta S, et al. 2008. Downregulation of PAR-4, a pro-apoptotic gene, in pancreatic tumors harboring K-ras mutation. Int J Cancer. 122:63-70.

Azmi AS, Ahmad A, Banerjee S, Rangnekar VM, Mohammad RM, Sarkar FH. 2008. Chemoprevention of pancreatic cancer: characterization of Par-4 and its modulation by 3,3' diindolylmethane (DIM) Pharm Res. 25:2117-2124

Bingle, L., Brown, N.J., and Lewis, C.E. 2002. The role of tumour-associated macrophages in tumour progression: implications for new anticancer therapies. J. Pathol. 196, 254-265.

Bradford MM.1976. A rapid and sensitive method for the quantitation of microgram quantities of protein utilizing the principle of protein-dye binding. J. Anal Biochem.72:248-254.

Boehrer S, Chow KU, Beske F, Kukoc-Zivojnov N, Puccetti E, Ruthardt M, Baum C, Rangnekar VM, Hoelzer D, Mitrou PS et al. 2002. In lymphatic cells par-4 sensitizes to apoptosis by down-regulating bcl-2 and promoting disruption of mitochondrial membrane potential and caspase activation. Cancer Research 62 1768-1775

Burikhanov R, Zhao Y, Goswami A, Qiu S, Schwarze SR and Rangnekar VM. 2009. The tumor suppressor Par-4 activates an extrinsic pathway for apoptosis. Cell 138: 377-388.

Casciola-Rosen L, Nicholson DW, Chong T, Rowan KR, Thornberry NA, Miller DK, et al. 1996. Apopain/CPP32 cleaves proteins that are essential for cellular repair: a fundamental principle of apoptotic death. J Exp Med.183:1957-1964.

Cha YI, DuBois RN. 2007. NSAIDs and cancer prevention: targets downstream of COX-2. Annu Rev. Med. 58:239-252.

Cheema SK, Mishra SK, Rangnekar VM, Tari AM, Kumar R, Lopez-Berestein G. 2003. Par-4 transcriptionally regulates Bcl-2 through a WT1-binding site on the bcl-2 promoter. J Biol Chem.278:19995-20005

Colotta, F., Allavena, P., Sica, A., Garlanda, C., and Mantovani, A. 2009. Cancerrelated inflammation, the seventh hallmark of cancer: links to genetic instability. Carcinogenesis 30: 1073-1081.

Condeelis J, Pollard JW. 2006. Macrophages: obligate partners for tumor cell migration, invasion, and metastasis. Cell.124:263-266

Cook J, Krishnan S, Ananth S, Sells SF, Shi Y, Walther MM et al. 1999. Decreased expression of the pro-apoptotic protein Par-4 in renal cell carcinoma. Oncogene 18: 1205-1208.

Craig M, Ying C, Loberg RD. 2008.Co-inoculation of prostate cancer cells with U937 enhances tumor growth and angiogenesis in vivo. J Cell Biochem. 103:1-8.

Dibra D, Mishra L. and Li S. 2014. Molecular of Oncogene-Induced Inflammation and Inflammation-Sustained Oncogene Activation in Gastrointestinal 
Tumors: an Underappreciated Symbiotic Relationship. Biochim Biophys Acta. 1846: 152-160.

Dillon RL., White DE. and Muller WJ. 2007. "The PhosphatidylInositol 3-Kinase Signaling Network: Implications for Human Breast Cancer." Oncogene 26: $1338-45$.

Faurobert E, Bouin AP, Albiges-Rizo C. 2015. Microenvironment, tumor cell plasticity, and cancer. Curr Opin Oncol. 27:64-70.

Flis S, Soltysiak-Pawluczuk D, Jedrych A, Jastrzebski Z,Remiszewska M,Splawinski J. 2006. Antiangiogenic effect of sulindac sulfide could be secondary to induction of apoptosis and cell cycle arrest. Anticancer Res 26:3033-3041

Gala M, Ronggai Sun R, and Yang VW.2002. Inhibition of cell transformation by sulindac sulfide is confined to specific oncogenic pathways. Cancer Lett.175: 89-94.

Gurpinar E, Grizzle WE, Piazza GA. 2014.NSAIDs inhibit tumorigenesis but how? Clin Cancer Res.20:1104-1113

Hanchen Li, Xueli Fan, and JeanMarie Houghton. 2007. Tumor Microenvironment: The Role of the Tumor Stroma in Cancer. Journal of Cellular Biochemistry 101:805-815

Joyce, J.A. and Pollard, J.W. 2009. Microenvironmental regulation of metastasis. Nat. Rev. Cancer 9: 239-252.

Klemm F and Joyce JA. 2015. Microenvironmental regulation of therapeutic response in cancer. Trends Cell Biol.25:198-213.

Kogel D, Reimertz C, Mech P, Poppe M, Fruhwald MC, Engemann H et al. 2001. Dlk/ZIP kinase-induced apoptosis in human medulloblastoma cells: requirement of the mitochondrial apoptosis pathway. Br J Cancer 85: 18011808

Kwan ML, Habel LA, Slattery ML, Caan B. 2007. NSAIDs and breast cancer recurrence in a prospective cohort study. Cancer Causes Control. 18:613-20

Leibovich-Rivkin T, Liubomirski Y, Meshel T, Abashidze A, Brisker D, Solomon H, Rotter V, Weil M and Ben-Baruch A. 2014. The inflammatory cytokine TNF $\alpha$ cooperates with Ras in elevating metastasis and turns WT-Ras to a tumor-promoting entity in MCF-7 cells.BMC Cancer14:158.

Livak KJ and Schmittgen TD. 2001. Analysis of relative gene expression data using real-time quantitative PCR and the $2-\Delta \Delta C$ T. Methods.25:402-8.

Moreno-Bueno G, Fernandez-Marcos PJ, Collado M, Tendero MJ, RodriguezPinilla SM, Garcia-Cao I et al. 2007. Inactivation of the candidate tumor suppressor par-4 in endometrial cancer. Cancer Res 67: 1927-1934.

Nalca A, Qiu S. G, El-Guendy N, Krishnan S and Rangnekar V. M. (1999): Oncogenic Ras sensitizes cells to apoptosis by Par-4. J. Biol. Chem. 274: 29976-29983. 
Piazza GA, Keeton AB, Tinsley HN, Gary BD, Whitt JD, Mathew B, et al. 2009.A novel sulindac derivative that does not inhibit cyclooxygenases but potently inhibits colon tumor cell growth and induces apoptosis with antitumor activity. Cancer Prev Res. 2:572-578.

Qian BZ. and Pollard JW. (2010). 2010. Macrophage Diversity Enhances Tumor Progression and Metastasis. Cell. 141: 39-51.

Ranganathan P and Rangnekar VM. 2005. Regulation of Cancer Cell Survival by Par-4. DOI: 10.1196/annals.1339.04

Roberts PJ and Der CJ. 2007. Targeting the Raf-MEK-ERK mitogen-activated protein kinase cascade for the treatment of cancer. Oncogene. 26:3291-3310

Siegel, R., Miller, K., \& Jemal, A. 2015.Cancer statisitcs, 2015. A Cancer Journal for Clinicians, 65(1), 5-29.

Skehan P, Storeng R, Scudiero D, Monks A, McMahon J, Vistica D, et al. 1990. New colorimetric cytotoxicity assay for anticancer drug screening. J Natl Cancer Inst.82:1107-12.

Zhang $\mathbf{Z}$ and Dubois RN. 2000. Par-4, aproapoptotic gene, is regulated by NSAIDs in human colon carcinoma cells. Gastroenterology 11:1012-1017.

Zhao YS, Zhu S, Li XW, Wang F, Hu FL, Li DD, et al. 2009. Association between NSAIDs use and breast cancer risk: a systematic review and meta-analysis. Breast Cancer Res and Treat. 117:141-150. 


\section{كبريتيد السولينداكك يستحث الموت المبرمج لخلايا سرطان الثدي المنشطة في نموذج زراعة}

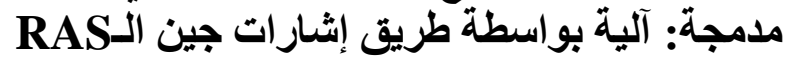

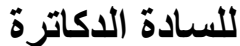

ناديه عبدالنبي ثابت'، ناديه محمد الجندي'، مني مصطفي محمد'، ساميه عبدالسميع شومان'

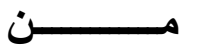

'قسم بيولوجيا الاورام، المعهد القومي للاورام ، جامعه القاهره، الجيزه با آب ا، مصر.

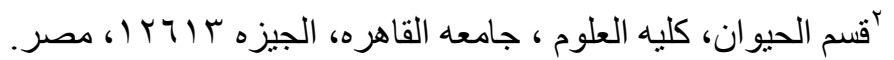

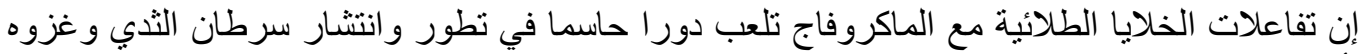

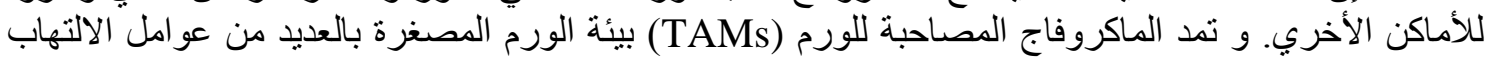

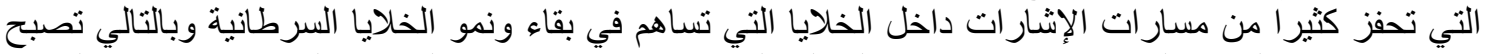

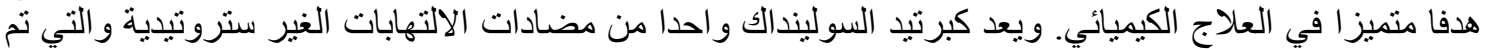

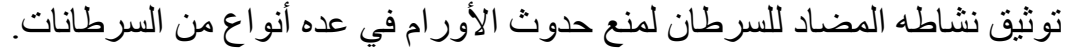

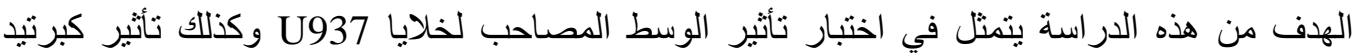

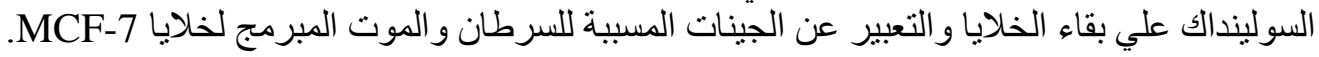

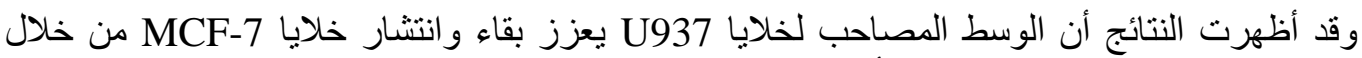

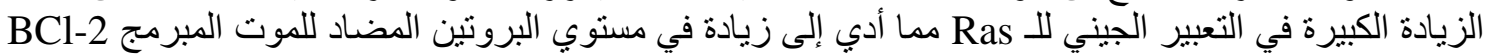

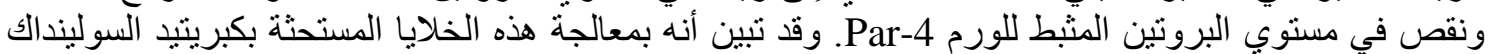

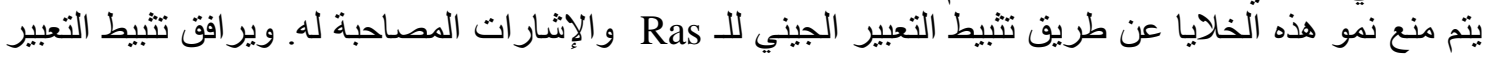

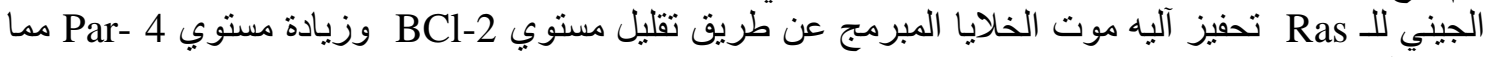

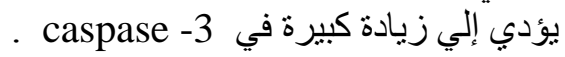
وقد أظهرت النتائج الحالية أن كبرتيد السوليداك قد قد نجح في إحباط الثأثير الجانبي لخلايا الماكروفاج

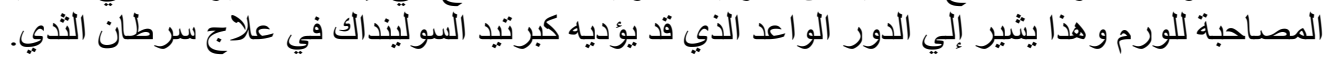

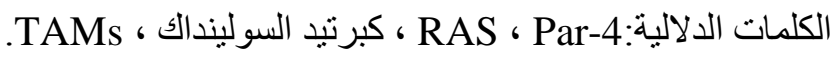

